\title{
A vision for Southland
}

\author{
GRANT CATTO \\ Farmer, Heddon Bush, Southland
}

Keywords: animal welfare, dairy farming, deer farming, environment, genetic engineering, horticulture, organic farming, sheep farming

I farm two properties with my wife and parents, one at Heddon Bush and the other a run block at Mossburn. Many people in the late 1980s were either exiting farming or expanding while land prices were low. We chose to expand as our area of 137 ha at Heddon Bush of good land was no longer an economic sheep unit, so we purchased 61 ha of hill country at Mossburn.

Southland farming has been dominated by sheep farming in the past, and will be in the future. However, with the present decline in sheep and cropping incomes, and the rise in profitability of dairy farming, forestry, deer farming and the expansion in horticulture, we saw a progressive change in land use during the 1990s. For example, in 1989 when travelling between farms, we would pass only one dairy farm, now we pass nine, many are on less-than-prime dairy land and they are relatively large. There is still only one cropping farm, but one deer farm has now got three fellows. However, there are still no ostrich farms. I believe this sort of dramatic change is likely to continue, providing a wider and more stable economic base to the Southland economy, and a less volatile income stream to the rural towns, contractor and service industries.

Dairy farming's profitability means it will still continue to be the winner in the land grab. The eventual demise of the Dairy Board monopoly will allow for greater foreign investment in the industry so the growth of dairying in Southland will continue, although it will be based more on returns from marketing and distribution. An added bonus is that dairy farming brings young families to the rural communities - good for our schools, clubs and communities. The dairy industry will become a comfortable, second largest industry in the future.

The forestry industry, on the other hand, will have a major effect on our marginal land, where already thousands of hectares have been planted. The advent of Carbon Credits is only likely to increase foreign investment in this industry and consequently increase the demand for suitable land. Once planted, this land is unlikely to return to any other land use. The sheep and beef industries are positive at the moment, but each time these industries have a downturn, the forestry groups will be able to acquire more land. Farmers will also continue to plant as an investment.

Southlanders are becoming more entrepreneurial in the way they approach their farming enterprises. The rapid growth of the deer industry is a good example. The deer industry compliments the sheep and beef industries and will continue to expand as farmers can afford to convert using their own income. Beef offers farmers more income diversity, and a lower workload, especially as farm size continues to grow.

Horticulture is a relatively new and small industry in Southland. Farmers are seriously looking at this industry and are venturing in on a small but expanding scale, as growers learn and share knowledge, and as pioneers show it can be a profitable alternative. The lack of volume, continuity and consistency of supply limits this industry at present. In 20 years, I see floriculture as a mainstream industry in Southland. As the industry grows, the opportunities will increase, and so too will the profitability, volumes and quality improve. A qualified workforce will need to be established to work in what is a labour-intensive industry. Floriculture also offers an opportunity for people to gain equity for farm ownership from a small area, e.g., through the multiplication of bulbs for distribution or retention. With shearing no longer an avenue for farm ownership, this may become a new pathway for prospective sheep farming families to buy into a farm.

Organic farming is a small but important industry in Southland. Its future, like the others, is dependent on market access and profit margins. I see this industry remaining relatively minor in the future. However the arrival of genetically engineered (G.E.) organisms will change that. A much larger G.E. free market is likely to develop and a lack of G.E. organisms on a property will almost equate to the farm being organic. The criteria for organic labelling will become more lenient and food safety will become the real issue resulting in a steady increase in the number of Southland properties being labelled as organic.

I see three key issues facing all of these industries in the future: animal welfare, environmental concerns and genetic engineering. 
Animal welfare and environmental issues will be most visible to tourists in Southland. Currently they see us mostly from the Queenstown to Milford highway. When Stewart Island becomes a National Park, more tourists, and especially environmentally aware ones, will travel through the farming centre of Southland, Invercargill and Oban. It will become more important for the image portrayed overseas to match the reality. Wintering cypress, dead stock and animals in poor condition will be eyesores to be aware of. Overseas politicians and lobby groups will also promote their own interests, especially if we get any gains in the next W.T.O. round. Paperwork will become an increasing part of our farming business, to prove our environmental cleanliness, and to justify the necessity of some of our operations.

Issues like water quality, especially nutrient runoff, need addressing. Whether we like it or not, at some stage in the future, we will have to address the way we manage our riparian areas. Fencing off waterways and drainage channels will be necessary. We will probably have to keep nutrient diaries to show we are not applying excessive amounts of fertiliser.

However, genetic engineering is likely to have the most dramatic effect on our farming systems. In the near future each farmer is going to have to make a decision on whether they are going to grow G.E. plants, farm G.E. animals, or feed G.E. supplements. In the end it will become an individual decision, much like the choice between organic or conventional farming is now.

Most farmers are not utilising the genetic potential of their livestock, and average industry production figures show this. So I see the first real gains in being able to improve the grassland species that we use. This may take several forms: cost reduction, e.g., producing legumes that can compete for phosphorus as well as against brown top, meaning less super for more clover growth, i.e., more bloat and bigger lambs. Then perhaps we could change the clover again to give it the cool season growth of an Italian ryegrass, or perhaps change a ryegrass to have the quality of a clover, meaning better production, and faster growth rates.

Environmental issues could come into the equationto meet New Zealand's methane gas reductions some new rumen bacteria may be produced that stock could be inoculated with. These bacteria might also improve feed conversion removing the necessity to change our pasture species to improve animal performance.

Our livestock are perhaps a different story, and personally I'm much happier eating meat from a nonG.E. animal. Initially the role of G.E. in our animal industry will be to identify truly superior genes and allow the best animals to be bred from. It will be a geneticists dream, screening our replacement stock for desirable traits, and selecting our sires on true genotype rather than on an estimate of genotype from the phenotype. If our competitors, as farmers, or chicken or pork producers, use genetic engineering then we may be forced to use it to compete. This technology will allow us to make substantial gains in our productivity and profitability in the future. For Southland, a province reliant on agricultural earnings, this would be a good thing.

As for me and my family, we'll keep farming sheep and cattle. The types of properties we pass on the road will continue to change, as will the way we farm. Along with the rest of Southland, we hope to enjoy many golden summers in the future as part of Southland's booming agricultural industry. 